\title{
Retraction Note: Disruption of the Bcr-Abl/Hsp90 protein complex: a possible mechanism to inhibit Bcr-Abl-positive human leukemic blasts by novobiocin
}

\author{
L. X. Wu J. H. Xu • K. Z. Zhang • Q. Lin $\cdot$ X. W. Huang • C. X. Wen • Y. Z. Chen
}

Published online: 8 April 2020

(c) The Author(s), under exclusive licence to Springer Nature Limited 2020. This article is published with open access

\section{Correction to: Leukemia}

$$
\text { https://doi.org/10.1038/leu.2008.89 }
$$

The authors have retracted this article [1]. An investigation by Fujian Medical University identified multiple errors in the assembly of the figures, most notably in the duplication of loading controls. All authors agree with this retraction.

Open Access This article is licensed under a Creative Commons Attribution 4.0 International License, which permits use, sharing, adaptation, distribution and reproduction in any medium or format, as long as you give appropriate credit to the original author(s) and the source, provide a link to the Creative Commons license, and indicate if changes were made. The images or other third party material in this article are included in the article's Creative Commons license, unless indicated otherwise in a credit line to the material. If material is not included in the article's Creative Commons license and your intended use is not permitted by statutory regulation or exceeds the permitted use, you will need to obtain permission directly from the copyright holder. To view a copy of this license, visit http://creativecommons. org/licenses/by/4.0/.

\section{Reference}

1. Wu LX, Xu JH, Zhang KZ, Lin Q, Huang XW, Wen CX, Chen YZ. Disruption of the Bcr-Abl/Hsp90 protein complex: a possible mechanism to inhibit Bcr-Abl-positive human leukemic blasts. Leukemia. 2008;22:1402-9. 